\title{
TOMMY KUUSELA
}

\section{In Search of a National Epic}

The use of Old Norse myths in Tolkien's vision of Middle-earth

I $\mathrm{n}$ this article some aspects of Tolkien's work with regard to his relationship to folklore and nationalism are presented. It is also argued, contrary to Lauri Honko's view of literary epics, that pre-literary sources constitute a problem for the creators of literary epics and that their elements can direct the choice of plot and form. Tolkien felt that there was a British - but no English - mythology comparable to the Greek, Finnish or Norse ones. He tried to reconstruct the 'lost mythology' with building blocks from existing mythologies, and dedicated his work to the English people. In this, he saw himself as a compiler of old source material. This article considers his use of Old Norse sources. With Honko's notion of the second life of folklore it is argued that Tolkien managed to popularise folklore material while his efforts to make his work exclusively English failed; for a contemporary audience it is rather cross-cultural.

The WORKs OF John Ronald Reuel Tolkien (18921973) can be defined as an effort to create a national epic. In this process he salvaged old languages, myths and legends from fragments that formed the building blocks for his emerging secondary world, known as Middle-earth. In this article I will concentrate on examples where Tolkien used Old Norse myths and legends in his earliest writings, before The Lord of the Rings (LOTR), with The Hobbit as the intermediate position. Virtually every day of his working life as a professor of Anglo-Saxon, and later of English language and literature, he found himself reading, teaching or discussing works such as Beowulf, the Poetic $E d d a$, the Icelandic Sagas or Snorri Sturluson's Prose Edda and Heimskringla. Below I will also sketch a background that shows how his writings and interest in Norse myths and legends were similar to other European nationalistic projects.
The great Finnish folklorist Lauri Honko categorised the diversity of epic forms as follows:

By way of definition it seems useful to divide the multifaceted world of epics into three main categories: 1) literary, 2) semi-literary or tradition-oriented, and 3) purely oral epics. Literary epics are ... great narratives created by a writer or poet; an example would be John Milton's Paradise Lost. Virgil's Aeneid also belongs to this category. The form and structure of literary epics are decided by the literate poet, and if there is some reference to pre-literary sources and traditions, these elements do not direct the choice of plot or form. In short, these preliterary sources do not constitute a problem for the creator of a literary epic. He is the master of the elements available. (Honko 1998: 10; Honko 2000: 6-7)

Honko showed more interest in categories two and three, but this article will explore the first category - the literary epic - through the mind of Tolkien and his lifelong labour to create what can be called an effort to establish a national epic, posthumously published as The Silmarillion, Unfinished Tales, Tales from the Perilous Realms, The Legend of Húrin, and The History of Middle-earth in twelve volumes. In the following I will argue, against Lauri Honko, that pre-literary sources do indeed constitute a problem for the creators of literary epics and that that their elements can directly influence the choice of plot and form.

The publication of Tolkien's secondary world, with all its variations and different forms, offers us the opportunity to gain an understanding of the artistic development of one of the twentieth century's 
most influential writers. His texts began as something that can be characterised as a 'traditional mythology', usually as poems following Old or Middle English metres, but ended up as something else. In early writings he imagined the creation of a body of interconnected legends that would fill the gap for a specifically English mythology (as opposed to Celtic, Arthurian or Norman). This project was in tune with the historical thinking of his era. In Edwardian times (1901-10) the Romantic interest in Northern European mythological texts was still strong. Myths and language were considered an important part of a nation's heart and soul. The early works were filled with fairies, gods and magic, combined within a nationalistic framework. Gradually it turned out that Tolkien had created something quite different; the crucial turn came with the publication of The Hobbit (1937), a story which had emerged from telling stories to amuse his children, and later with the demand for its sequel, which in time became more ambitious and developed into the LOTR, published 1954-5.

During his earliest writing phase Tolkien was primarily constructing a mythology, imitating ancient as well as medieval myths and legends, and developing his own creation myths. In this process he shaped a pantheon of gods and semi-divine creatures and fashioned epic tales of great heroes set in ancient times (that is, thousands of years before the events depicted in the LOTR, according to the chronology of his narratives). Tolkien experimented with different modes of writing and frequently used long poems to describe events. After the publication of The Hobbit and the LOTR he settled for a novelistic mode, but never gave up poetry or songs, which were embedded in his narratives. In these later accounts he turned to a more historical mode of writing and used his older mythological material as a framework for the tales, revealing occasional glimpses of a much richer (and older) history; for example through songs or allusions to older legends of Middle-earth. It would not be wrong to suggest that with the LOTR Tolkien's writing changed in style from 'myth and legend' to 'history'; he never completed his collection of legends for publication; the new work altered too many of his former ideas and views so that the rifts became contradictory. The legends were still important, but for entirely different reasons and could be used as a contextual background for his new stories. Tolkien frequently referred to his work by using the term mythology, with or without quotation marks, and his use is far from consistent. Tolkien himself never used the term 'a mythology for England', a term found in numerous Tolkien studies; it was actually first introduced by and derives from his biographer Humphrey Carpenter (cf. Stenström 1995, Chance 2004).

Despite his ambitious project to create a mythology that he wanted to dedicate to the English people, his plans were flawed. He struggled to recapture a lost tradition based on philology and old North European myths (including Old and Middle English texts). If we compare Tolkien to, for example Elias Lönnrot or the Grimm brothers, we can easily see what's missing. Lönnrot systematised a large collection of Finnish folk poetry into a series of interconnected mythological poems. The Grimm brothers also depended heavily on the gathering of folktales and compiled their narratives according to different tale types. But Tolkien lacked this kind of material and was basically 'inventing' from scratch; his dependence on philology and his non-involvement with folklore turned his ambitions into a mountain that he could never climb. Tolkien was no expert on folklore, at least not as an academic discipline, but he knew enough to be able to comment on some of its methods. In his essay On Fairy-Stories (presented as the Andrew Lang Lecture 1939 at the University of St Andrews, revised for print 1947) he refers to the intense debate on the origins of fairytales and speaks of both Max Müller and Andrew Lang with an understanding and awareness of their theoretical frameworks. His reaction to folklore was by today's

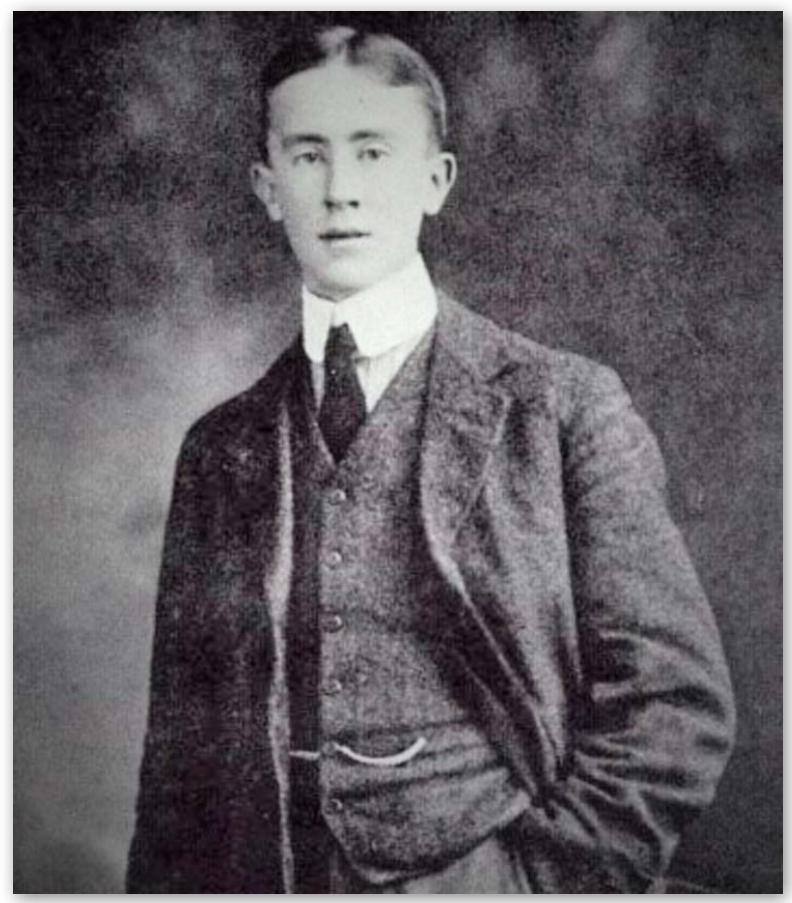

J.R.R. Tolkien as a young man, around 1911, some years before he started writing his literary epic. 
standards rather old-fashioned, and he seems to have been of the opinion that folktales are a corrupted form of ancient myth. In the same essay he speaks of myths and folktales as being 'higher' and 'lower' mythologies respectively (Tolkien 2008: 42). I will not delve into this topic more than is necessary, but it should be noted that Tolkien did not primarily work with the oral tradition: his interest was rather in the written word; medieval texts and ancient poems and to some degree, their authors and the context of their topics.

\section{A conflicting twofold vision: nationalism vs. sub-creation}

Why did Tolkien choose literature as his forum for presenting his national epic? One answer is that literature had at least since the seventeenth century played a central role in English cultural life and was in Krishan Kumar's words: 'put on a national pedestal as the first deity of the English nation. For many people, literature - not Parliament or the monarchy - was England' (Kumar 2003: 220). This was fuelled by the First World War, where the importance of a canon of English literature, based on the native language and literature, sustained the morale and patriotic pride of the soldiers. This is the same period as Tolkien started writing on his secondary world. ${ }^{1}$ But he still had to find some way to harmonise his fiction with real history. For the mythologists of the nineteenth century - as well as for Tolkien - the major problems were, as Tom Shippey (2007: 89) has shown:

1. To rediscover a lost unity of belief, along the lines of the linguistic science of 'reconstruction' in which they all firmly believed.

2. To press this into the service of their major or minor language groups: German, Danish, Scottish, Frisian, Swedish etc.

3. To reconcile it with their own Christian professions.

Tolkien thought of himself as a kind of mediator who gathered ancient knowledge and who transcribed and

1 He fought at the Battle of the Somme in the First World War where he contracted trench fever and was sent home to a hospital for some months during 1916 and 1917. Tolkien never returned to the war, instead he was posted to camps in England until the end of the war. Cf. Garth 2003. restored it for later societies. ${ }^{2}$ As a transitional scholarly scribe, or a compiler of 'ancient records', Tolkien followed a model formed by earlier 'philologistcreators', whose claims to define the importance - and reconstructions - of national identity were equally literary and linguistic (Shippey 2001: xv). Included in this group with Lönnrot and his contemporaries, are the German brothers Jacob and Wilhelm Grimm, the Danes Nikolaj Frederik Severin Grundtvig and his son Sven, the Serb Vuk Stefanović Karadžić, the Frenchman Emmanuel Cosquin, the Pole Adam Bernard Mickiewicz, the Icelander Jón Árnason and the Norwegians Jørgen and Moltke Moe, whose editions of and notes on Norwegian folktales and legends, together with collections of ballads, became the foundation of the Norwegian Folk Archives. In Sweden G. O. Hyltén-Cavallius and George Stephens were important collectors of folklore; for the former it was a part of a nationalistic urge and love of the rural in contrast with modern society (cf. Eriksson 2013, Bringéus 1966). To this list the Norwegian historian, Peter Andreas Much, might be added, who also used his knowledge of language, poetry, history and folklore to establish the foundations for Norway's national history. The common theme among all these was that they all responded to the national idealisation sweeping through Europe in the nineteenth century. ${ }^{3}$ During this period a nation's language was recorded through folklore and sanctioned through literature to the point where it 'became a means of defining the identity of a nation' and if the 'traditions they found appeared fragmentary and deteriorated; it was the task of the collectors and editors to "restore" them' (Kvideland and Sehmsdorf 1989: 4).

If we take Jacob Grimm as an example, the very title Deutsche Mythologie ('German Mythology') is provoking in itself, since much of the material used was Norse, not German. His work also contained the implicit claim that the Scandinavian people were really German; he was quite capable of cutting the Scandinavians out of his account. As early as 1823 he stated that all references to Danes and Swedes in Beowulf meant that it was German since the mythology mentioned in the poem was, according to him,

2 He seemed to think that some of the stuff he compiled already existed; it was something originating in a collective English imagination, and he was in that sense not inventing things from scratch.

3 In Scandinavia there was an idea of 'Scandinavism', promoting a shared Nordic past and cultural heritage, where language and Old Norse literature played a central part. 
unknown in Scandinavia at that time! This claim was immediately resented in Scandinavia, actually before his text was published, and faced a challenge from Grundtvig, who argued that the poem had Danish roots. English scholars joined in the academic battle, both on the Scandinavian and German sides, but claims for an English origin was rare. When Tolkien came into the field of philology and mythology in the twentieth century he could hardly avoid noticing an immense gap for his country and language group, which was filled for other countries by the works of men like Grundtvig, Lönnrot, Karadžić, Cosquin and especially Jacob Grimm. Still, he had nothing comparable to work with; England had almost no native mythical tradition, nor any poetic corpus based on it (cf. Roper 2012). In his famous lecture on Beowulf, delivered on 25 November 1936 to the British Academy, Tolkien admitted that the ancient English mythology had all but vanished, but said it could not have been that different from Norse (Tolkien 2002: 86-7). This might be one of the reasons why he considered Norse literature a good starting point when trying to reconstruct his own country's ancient legends in support of an English national self-image. It must be said that Tolkien - whose lecture is often considered to be the beginning of modern Beowulf criticism sharply criticized earlier and contemporary critics' excessive interest in the poem as a historical source. He felt that Beowulf should be studied as a work of art, and that its qualities as poetry overshadow any historical contents: 'Beowulf is in fact so interesting as poetry, in places poetry so powerful, that any historical value it may possess must always be of secondary importance' (Tolkien 2002: 84). In Tolkien's view Beowulf was not an epic; he would rather describe it as a heroic-elegiac poem.

Nationalistic dreams of a glorious past were also reflected on the age of the folklore material; the older it was and the further back it could be traced, the more valuable and exciting. The Romantics thought that the old folk tradition lay in ruins and was in need of restoration or reconstruction. It was just waiting for the right man (it was seldom a woman) who could revise and publish it for the masses, which usually meant the bourgeoisie.

Tolkien's project to create a mythology for England shows a twofold vision: at times Tolkien was overwhelmed with a nationalistic desire to create an English counterpart that could stand alongside the Celtic, Norse, Greek, Roman or Finnish mythologies; at other times he felt an urge for 'sub-creation' - independent of nationality - according to his own philosophical and religious views. When he became older he became more and more preoccupied with the spiritual themes of his creation, and more or less abandoned his nationalistic ideas (but was still interested in its Englishness ${ }^{4}$ ). At times the nationalistic and the religious visions competed in Tolkien's mind, which might explain some of the inconsistences in Middle-earth (this is apparent thanks to the posthumous works published by his son). Sometimes his visions went hand in hand and both shaped and gave life to his secondary world. The nationalistic urge was essential for a younger Tolkien, but lessened with time when spiritual themes became dominant. Tolkien was a devout Roman Catholic and tried to explain his urge to create a secondary world as a small creation within a much greater primary creation, which was God's creation. In his lecture on folktales and in his letters he made it explicit that he was just a sub-creator, inspired by and working inside of God's creation (Tolkien 2008: 59-61, 78; Tolkien 2000: 145-6, 188$9,195)$. This was one of his underlying themes and made it possible for him to merge elements from the primary world with his imagination in the secondary world. Martha C. Sammons, writing on Tolkien and his friend C. S. Lewis's visions of imagination and art, concludes that in their view: 'fairy stories, myth, and fantasy are imperfect glimpses and shattered reflections of the Truth God tells in the Great Story. Nevertheless, the gift of making in God's image allows the fantasy writer to recombine, rearrange, remythologize, reenvision, resacralize, and, at last - to relinquish' (Sammons 2010: 191).

Most mythologies and folk narratives, such as the Finnish epic The Kalevala, are presented to the public by collectors like Lönnrot, who functions as the editorial bridge between old (mostly oral) stories and the audience reading the text. Even though Tolkien deeply admired The Kalevala he had no ambition to be a folklore collector. He dismissed much of what he called English 'impoverished chap-book stuff' and desired to be the sole creator of an interconnected fictive mythology. In a letter dated 1951 he wrote:

4 This can be seen in his elevation of the English countryside, a love he shared with such persons as William Morris and Thomas Hardy. The essential England was rural; it was in the countryside, not the cities, that hopes for a cultural and spiritual renewal were to be found. For Tolkien this is most clearly seen in his descriptions of the Shire and its place names (comparable to rural England and its farmers) and in his critique of industrialisation. 
...once upon a time (my crest has long since fallen). I had in mind to make a body of more or less connected legend, ranging from the large and cosmogonic, to the level of romantic fairy-story ... which I could dedicate simply: to England; to my country. (Tolkien 2000: 144)

To design a mythology is one thing, but to persuade an actual reading public of its authority not just as myth but as their myth - however fictive - is something else. Tolkien's own mythology might be compared to what he says of the Beowulf poet, in that it is meant to give 'the illusion of surveying a past, pagan but not ignoble and fraught still with a deep significance, a past that itself had depth and reached backward into the mists of countless human sorrows' (Tolkien 2002: 139). The single concept of constructing a wholly invented mythology, and trying to make it English through the idea of ancestrally transmitted memories from English myth and history, might sound overambitious and absurd (which he himself noted in the quoted letter). But even if his project is incomplete, it is a complex and passionate vision of a fictive meeting place between English history and English myths. Tom Shippey places the creation of national myths, and by extension Tolkien's ambitions, in the light of the concept of a mythological arms race'; the desire of European cultures to stake a claim for nationhood through myths. For some military and political force rested on the secure possession of national epics (Shippey 2007: 82). This Romantic ideology often went hand in hand with national expansion as well as national distress.

A British 'national identity' including Scotland and Wales emerged rather late, during the eighteenth and nineteenth centuries, and from the nineteenth century, Ireland was also included. It took a long time for the waves of nationalism sweeping through Europe to wash ashore in England. One explanation is the formation and successful expansion of the British Empire which reached its peak during this period. The dominant and leading role of the English in the creation of and maintenance of the Empire was never challenged, until the Irish did so in the twentieth century. The English were aware that the multinational entity comprising Britain and the Empire was their creation, and it made the need for a pure English nationalism counter-productive; to stress English superiority over other British people would have threatened the unity and the integrity of the structures the English had constructed (Kumar 2003: 178-9).
The typical pattern for European nationalism was to associate the nation with a glorious past and praise its virtues. A new emphasis on ethnicity at the end of the nineteenth century promoted the idea that every nation had its own 'national soul', a distinctive cultural heritage that marked it out from others. In a way this was, as Benedict Anderson has pointed out, the formation of imagined communities where nations could idealise their past, construct their own national identities and perceive themselves as belonging to that group (Andersson, B. 2006). One way for the English was to search for a 'Golden Age' of the Anglo-Saxons before the Norman invasion, a period celebrated for its true English spirit of freedom, and a time when free institutions were alive and thriving. It was mainly during the end of the nineteenth century and the beginning of the twentieth that notions of the Anglo-Saxons grew and were cultivated further into a national myth; at the same period the British Empire started to move towards a stage of decline. Tolkien can be said to be a part of this movement; he was proud to be Anglo-Saxon by descent and undertook as his private task to provide for his country an outstanding and believable mythology. This does not mean that he praised the Empire (Tolkien detested imperialism and longed for an English identity separate from the Empire). During World War II he wrote on fear of globalisation and patriotism to his son Christopher:

The bigger things get the smaller and duller or flatter the globe gets. It is getting to be all one blasted little provincial suburb.... Col[lie] Knox says that $1 / 8$ of the world's population speaks 'English', and that it is the biggest language group. If true, damn shame - say I. May the curse of Babel strike all their tongues till they can only say 'baa baa', it would mean much the same. I think I shall have to refuse to speak anything but Old Mercian. ... For I love England (not Great Britain and certainly not the British Commonwealth (grr!). (Tolkien 2000: 65)

When Tolkien started writing, a common view among English intellectuals was to praise the AngloSaxons as the ancestors of the modern English people (Fimi 2006: 160). Until the nineteenth century mythology usually meant either Classical or Biblical, but this changed with a growing awareness, and translations, of old poems. Beowulf is, as I mentioned earlier, an excellent example of how the 'rediscovery' of the manuscript (first transcribed 1818) sparked 
romantic notions of an Anglo-Saxon identity. The poem was for some even considered a national epic. In this period the recovery and interpretations of ancient mythology was, for many, of national interest in a contest for national authority and power. At this time the 'folk' (Volk) were being discovered - and when necessary, invented - by scholars. They were explored and interest was sparked in their lore and language, songs and dances, rural life and craftsmanship, customs and stories. All of these were collected and written down, and England was no exception to this folk mania sweeping over Europe (Kumar 2003: 208). The nineteenth century produced handbooks of different national mythologies and folklore and the era has rightfully been called the Golden Age of the writing of such handbooks (Lindow 2005: 23).

\section{Examples of Old Norse sources in the creation of Middle-earth}

Tolkien was attracted to Old Norse mythology and believed that the lost Old English myths could not have been much different. This is the main reason why they inspired him in the creation of a literary epic for the English. This kind of thinking is not unique and can be seen in the works of the great philologist, and one of the greatest authorities on Eddic poems as Tolkien was growing up, Sophus Bugge (1833-1907), who argued that the poems were actually composed in Britain. Similar views can be found in the philologist and polymath George Stephens' works among others. ${ }^{5}$ I will give a couple of examples of how Tolkien used Norse material and turned it into something new (more examples can be found in Burns 2005 and Simek 2005). One main source of inspiration was Snorri Sturluson's thirteenth-century Prose Edda, a text Tolkien knew well. In the prologue to that work, Snorri makes it clear that he as a Christian does not believe the stories he has written down. In the first section, called 'Gylfaginning', King Gylfi travels to the home of the gods to question them about the creation and the nature of the world. Gylfaginning means 'the deluding of Gylfi', and this is basically what happens in a question-and-answer

5 I am preparing an article on this subject. Bugge published this idea in two volumes as Studier over de nordiske gude- og heltesagns oprindelse 1881-9 and 1899. They were controversial and fiercely questioned, but would have suited Tolkien's own vision of the heroic past, a bridge that brought Old Norse and AngloSaxon together. The first volume was translated into German, and the second volume into English. form of narrative. The gods are, according to Snorri, nothing but influential and powerful humans who have managed to deceive the world around them, and made people believe that they are gods. ${ }^{6}$ They (the Æsir) give Gylfi all the answers he's looking for. This story is used by Tolkien when he describes how Eriol in a dream-state finds himself inside a cottage where three mysterious elves answer all his questions about the creation of the world, the gods and the nature of the world. There are also similarities between Tolkien and Norse sources in the outline and layering of the stories and poems constituting the Völsung Cycle, for example poems in the Poetic Edda and the the Völsunga Saga (cf. Andersson, T. 1980: 24-77; Aðalheiður Guðmunsdóttir 2012). Tolkien wrote to W. H. Auden in 1967 that he had once made: 'an attempt to unify the lays about the Völsungs from The Elder Edda, written in the old eight-line fornyrðislag stanza' (Tolkien 2000: 379). This was a reference to his then unpublished poems 'Völsungakviða en nýja' and 'Guðrúnarkviða en nýja' which are now edited and published by his son Christopher Tolkien in The Legend of Sigurd and Gudrún. His story of Túrin Turambar draws on the exploits of the greatest hero of Northern myth and legend, Sigurðr Fáfnisbani, most notably in the treatment of Túrin's killing of the dragon Fáfnir. Tolkien's story - which exists in different versions - is now published and edited by Christopher as The Children of Húrin and is also influenced by the Kalevala (Petty 2004, Kuusela 2013).

Another example of Tolkien's use of Norse material is that he insisted on writing dwarfs as dwarves, with the -ves ending, even though, as he says in a letter: 'Grammar prescribes dwarfs; philology suggests that dwarrows would be the historical form' (Tolkien 2000: 31). If $d w a r f s$ are considered the correct form, why not use it? The answer, according to Tom Shippey, lies in the idea that the -ves ending is often a sign of a word's antiquity. Even in modern English words ending in $-f$ make their plural with -ves, as long as they have been in constant use - for example, hoof/hooves, wolf/wolves, loaf/loaves or thief/thieves. Dwarves might have developed the same way, but fell out of general use, and was adjusted to the simple pattern of tiff(s), rebuff(s) and so forth. This was something Tolkien meant to change and, so

6 Snorri's use of Euhemerism was a common means of rationalising a heathen religion in the Middle Ages and is also used by his near contemporary Saxo Grammaticus in the Gesta Danorum (History of the Danes), written at the beginning of the thirteenth century. 
The Hobbit: Thorin Oakenshield, Balin, Bifur, Bofur, Bombur, Dori, Dwalin, Fili, Gloin, Kili, Nori, Oin, Ori and the wizard Gandalf

Volluspa: Porinn, Eikinskjaldi, Bifurr, Bǫmburr, Dóri, Dvalinn, Fíli, Glói, Kíli, Nóri, Óri and Gandálfr*

* Some of the names also appear in the Pulur in the manuscripts of Snorri's Edda, mnemonic verses and lists of names. I have used Neckel and Kuhn's edition of the poem where they make use of the different manuscripts, the stanzas including the names are stanza 11, 12, 13, 14, 15, 16, 22.

to speak, turn back time. ${ }^{7}$ The Grimm brothers had tried to do the same thing with the German plural form for 'elf', which ought to be Elben, not Elfen (Shippey 2001: 14-15; Shippey 2005: 157). As everyone who has read (or seen the movie of) The Hobbit knows, dwarfs are an important part of the story. Tolkien clearly had Voluspá in mind; a poem from the Poetic Edda where a couple of stanzas relate approximately 60 dwarf-names, mostly strung together in a rhythmic list; it's generally believed that this 'Dvergatal' is an interpolation into the poem. ${ }^{8}$ The 'Dvergatal' is repeated in a slightly different order in Snorri Sturluson's Prose Edda and Tolkien uses some names and forms that only appear in this version of the list. He modelled the names for Thorin and company in The Hobbit, together with other dwarf-names in his narratives, on this list; occasionally he deliberately altered some of the names.

It is characteristic for Tolkien in a way to ignore contexts, to seek suggestion and inspiration instead in words or in names. Most of the thirteen dwarfnames of Tolkien's Thorin and company can be found in versions of the 'Dvergatal', along with the names of Thorin's relative Dain (Dáinn), his grandfather

7 In an English translation by Arthur G. Brodeur of the Prose Edda, from 1916, the plural form dwarves is used consistently. This is contemporaraneous with Tolkien starting work on The Book of Lost Tales. There is no reason to believe that Tolkien was unaware of older texts using the same plural form that he preferred. What he did was to popularise the plural spelling dwarves for the noun dwarf, something that after the success of his books has become standard in most fantasy worlds (and also in some academic texts as well).

8 In a letter, dated 1967 , Tolkien said that: 'the name of the Dwarves in The Hobbit (and additions in the L.R.) are derived from the lists in Voluspá of the names of the dvergar; but this is no key to the dwarf-legends in L.R.' (Tolkien 2000: 383).
Thror (prór), and his father Thrain (Práinn). Thorin's nickname 'Oakenshield' can be found in the poem as 'Eikinskjaldi.' Tolkien did not just copy the list or use it as a source for names. He must have been inspired by the names and asked himself questions about them. Who, for instance, is this Gandálfr, and why is he in the list when the second name element is unmistakably álfr 'elf'? ${ }^{10}$ The same thing can be said of Eikinskjaldi, a name that appears two times in the poem (in stanzas 13 and 16), which - unlike the others - does not seem to be a proper name at all, but rather a nickname meaning 'with oaken shield'. For a personal name, moreover, we would expect Eikinskjoldr, instead of a dative singular form (cf. Salus and Beekman Taylor 1969: 76-7). In Tolkien's fiction it is a nickname, and the origin of that is first given in Appendix A (III) of the LOTR, but never in The Hobbit where Thorin Oakenshield is a main character.

The use of the name Gandalffr in Tolkien's narratives is more complex. In early drafts of The Hobbit Gandalf is used as a name for the chief dwarf, and what Bilbo sees that first morning is just 'a little old man. Even in the first edition a staff soon comes into the story, and in later drafts Gandalf has become 'an old man with a staff' and is far from being a dwarf (Andersson, D. 2002: 36). Tolkien must have interpreted the first element of the Old Norse word gandras 'staff' and the second element as 'elf'. Now, Gandalf in Tolkien's fiction is by no means any kind of elf, but neither is he an old man. Gandalf is a wizard with numerous names, a trait he shares with Odin from Old Norse mythology, and in Tolkien's fiction he seems elvish - that is to say, supernatural and alien - to humans. This is also a characteristic shared by the god Odin who travels in disguise among humans. Other elements of their descriptions also match; both Gandalf and Odin are described as wise old men with long beards and wide hats, travelling the world and initiating heroes, although there are many traits that separate them, for example ethically and in their choice of champions; Gandalf favours the morally strong, while Odin favours physically strong

9 Some of the dwarf-names can be translated with certainty, but in many cases the interpretations are sheer guesswork or at least problematic. Ursula Dronke tries to interpret all of the names in her translation and commentaries on the poem (Dronke 1997: 9-11, 122).

10 It must be said that Álfr also appears as a name for one of the dwarfs in stanza 16 of the poem. 


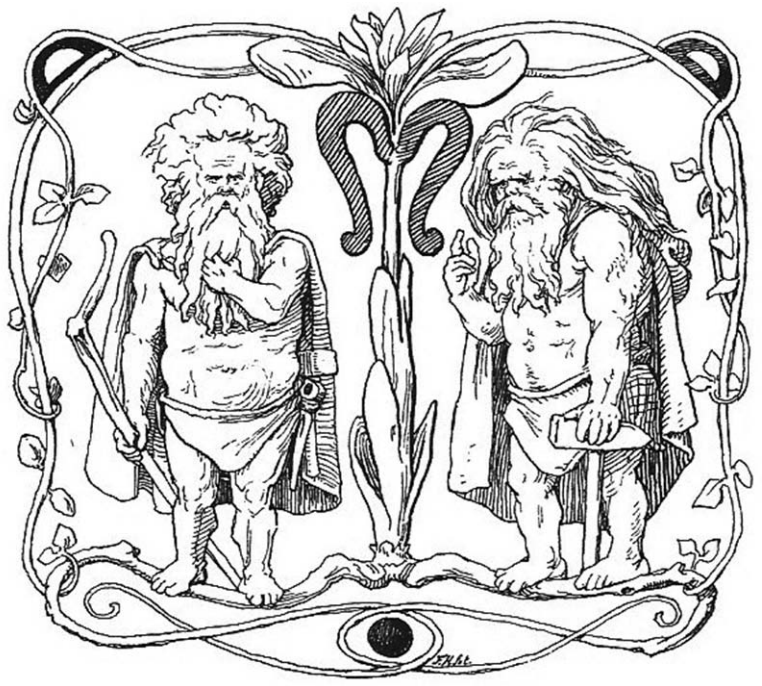

A picture of Old Norse dwarfs by the Danish painter Lorenz Frølich (1820-1908).

warriors. ${ }^{11}$ In Snorri's Heimskringla, there is a legendary Norwegian king called Gandálfr Álfgeirsson, suggesting that the name could be used of humans as well. William Morris, a known influence on Tolkien, used the name Gandolf for a character and Silverfax for a horse (compare Shadowfax, Gandalf's horse in LOTR) in his novel The Well at the World's End, published 1896. In the LOTR Éomer calls Gandalf 'elvish', a term that in the narrative is denotes something somewhat outlandish and supernatural. Tolkien probably thought that 'staff-elf' would be an appropriate name for a wizard who had somehow got mixed up with dwarfs, because the name is recorded in the 'Dvergatal'. It is typical of Tolkien's imagination that he thought that the name-list preserved a somewhat faded record of an account dealing with the most important dwarfs. It could be argued that Tolkien tried to restore and explain the story that lies behind the list; a story that would make sense of the 'Dvergatal' and by extension other stories about dwarfs, including folktales such as 'Schneewittchen' (Snow White). This is actually what he said in a letter written in 1937: 'Mr Baggins [The Hobbit] began as a comic tale among conventional and inconsistent Grimm's fairy-tale dwarfs, and got drawn into the edge of it' (Tolkien 2000: 26).

In Tolkien's Middle-earth dwarves are considered great craftsmen, smiths and miners. Part of their

11 In a letter to his British publisher Sir Stanley Unwin dated 1946 Tolkien described Gandalf as an 'Odinic wanderer' (Tolkien 2000: 119). personality is marked by pride and greed, and they are children of the earth. There is no female dwarf mentioned in Tolkien's works. All of these criteria are also true of dwarfs in the Old Norse tradition, and it is obvious that it greatly inspired Tolkien when he created his secondary world. ${ }^{12}$ Tolkien used old racial stereotypes conventionally applied to Jews when he described the dwarf's greedy personality, but he also made them heroic and there's nothing anti-Semitic in his writings. They were a scattered population, living in distinct regional groups, something that can also be compared to Jews living in the diaspora. For a contemporary audience the dwarfs from Tolkien's works are commonly known and copied again and again by writers of fantasy, roleplaying games, filmmakers, painters and so on. In this Tolkien has managed to 'save' the mythological dwarfs from oblivion and caused them to linger in popular traditions (on dwarfs in Germanic literature, cf. Battles 2005).

Another fascinating example that shows how Tolkien could combine both Anglo-Saxon and Old Norse sources and create something new is that of the shape-shifter Beorn, first introduced in The Hobbit. From the Anglo-Saxon poem Beowulf we find that the eponymous hero's name can be interpreted as 'bee-wolf' - enemy of the bees, the hive plunderer - that is to say, a bear (cf. Glosecki 1989: 202-5). Beowulf, however, is no bear, though he shows certain traits that can be associated with bears: great strength, stubbornness, bear-like wrestling tendencies and good swimming abilities, but he remains human throughout the story, with occasional indications that there may be something supernatural about him. The poem has been compared to and is, in my opinion, related to an Old Norse saga: The Saga of King Hrolf Kraki, where the head of King Hrolf's champions is called Boðvarr Bjarki. His nickname Bjarki means 'little bear.' His father's name is Bjarni 'bear', his mother's name is Bera 'she-bear' and it is clear that Bôðvarr himself is closely associated with the bear. His story is in parts also analagous to Beowulf's. The hero is eigi einhámr, 'not one-skinned' and he has the ability to transform, or send away his spirit, in the shape of a bear (on animal transformation in the Old Norse tradition, cf. Kuusela 2012). This occurs in an episode in the saga (Chapter 33) when he lies down and rests; at the same time a great bear appears on a battlefield and crushes everyone

12 These traits are common enough in folktales as well; we just have to think of the characters in 'Snow White' from the Grimm brothers' collection. 


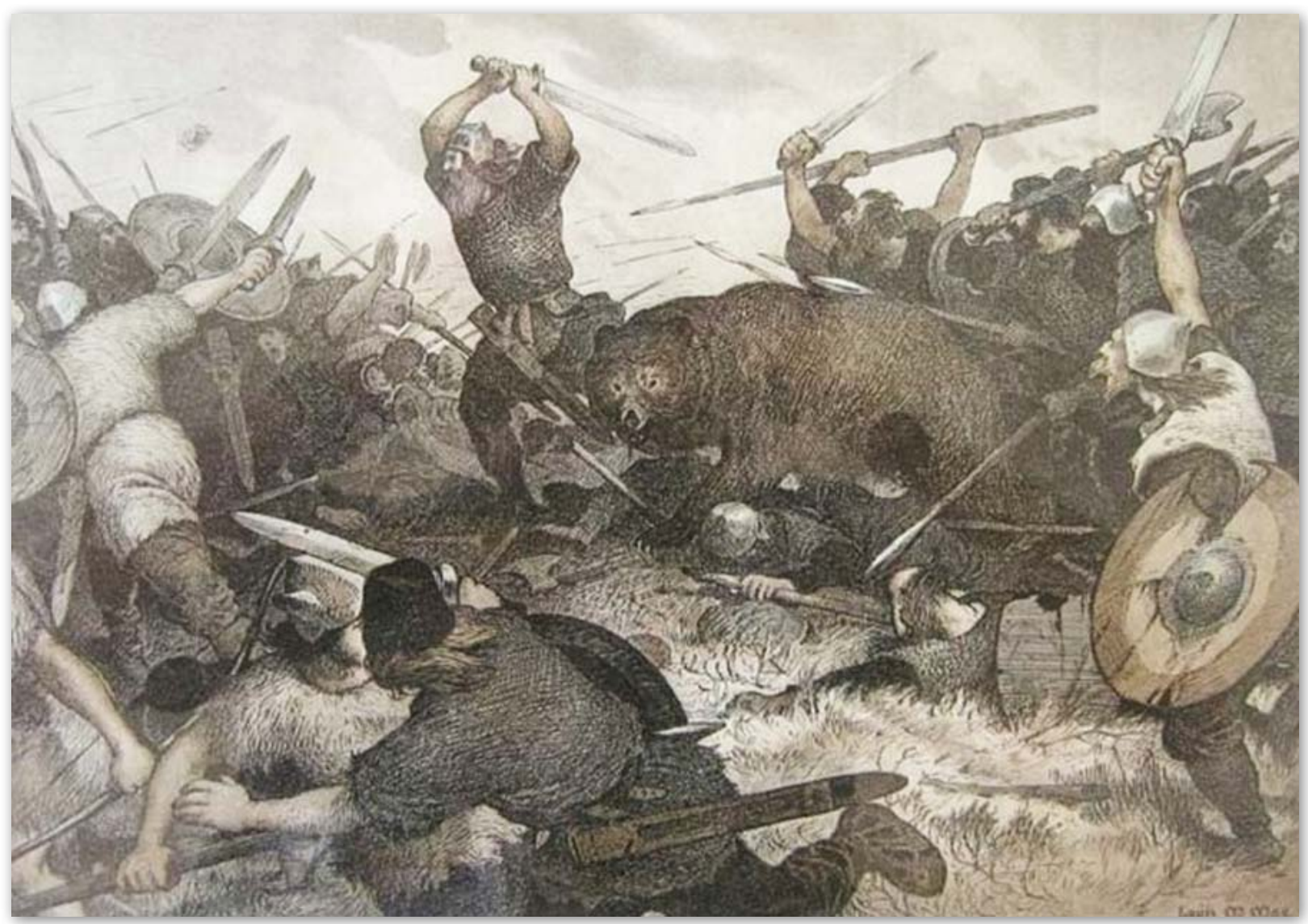

'Hrólfr Kraki's last stand' by the Norwegian painter Louis Moe (1857-1945).

who comes close to the King. Eventually he is disturbed, the bear disappears, and the battle is lost (The Saga of King Hrolf Kraki 1998: 73-7). Stories about heroes closely related to the bear are usually referred to as the 'Bear's son motif' (cf. Panzer 1910). Tolkien is obviously inspired by these stories when he introduces Beorn, whose name is the Old English equivalent of Bjarni, Boðvarr's father. The word can also be understood as 'man', but in the case of Beorn it is obvious that it signifies both connotations. In Tolkien's story Beorn appears in the final great battle on the battlefield as a great bear at a crucial moment and turns the tide, an episode obviously inspired by, but not copied from, the Icelandic saga. ${ }^{13}$ Beorn is

13 Another interesting example is that Beorn's hall is closely modelled (in function as well as layout) on the hall in both Anglo-Saxon and Norse heroic literature. Tolkien drew an illustration of Beorn's hall and it has been suggested that the source must have been a similar illustration (illuminating The Saga of King Hrolf Kraki) in his friend and colleague E. V. Gordon's An Introduction to Old Norse 1927, p. 28 (cf. Atherton 2012: 36-8). a skin-changer; his body really does change form by contrast with Boðvarr, whose spirit, in a shamanistic fashion, materialises as a great bear. It is characteristic of Tolkien that a name does not suffice without an explanation, which is something he gladly offers. His imagination is usually stirred by gaps, the unsolved, or left-out stories; from these he develops explanations built on a deep philological knowledge. The asterix, the root and the recreated word become, in Tolkien's mind, the seeds for a narrative. He excelled in extracting as much as possible out of fragmentary evidence or uncertain etymologies.

\section{The second life of folklore}

If we return to Lauri Honko, it should be clear that Tolkien's lifelong efforts to write a more or less interconnected body of legends can be categorised as a literary epic. This process was far from simple, and as I have tried to show, the source material also had an impact on the creator of epics in such ways that he could not freely create whatever he liked, but had to rely on his sources and philology. Honko spoke of how folklore changes with time and context and in 
accordance with different theoretical tools; one stage is the 'second life' of folklore (Honko 2013: 48-53). This interesting view of how folklore transforms and adapts in new environments is an appropriate way of describing how Tolkien reshaped old legends and myths and how - after his death - filmmakers and others have transmitted these ideas and concepts into contemporary popular culture. Honko called this procedure the 'recycling of folklore'; old material resurfaces in an environment that differs from its original cultural context, and influences new fields of interest; new groups of people come into contact with new forms of the folklore material. The most obvious case is of course the popular fantasy genre (literature, movies, video and computer games, toys, music, art, re-enactment, role-playing games etc.), which is heavily indebted to Tolkien's fiction, as well as myths and other forms of folklore.

I mentioned dwarfs but even more popular is Tolkien's concept of elves. In his earliest writings elves were tiny creatures rather close to Victorian fairies, but then he changed this conception drastically; he even postulated an Anglo-Saxon transmission of folktales, legends, sagas, poems, songs and lore down to our own day. This was explained through the character of the name 'Éarendel' in the Anglo-Saxon poem 'Crist', who was interpreted as 'a friend of the elves and bringer of light'. The first seeds for Middle-earth included this character in the poem 'The Voyage of Eärendel' written in 1914. One of his descendants was an Anglo-Saxon voyager and poet, at first named Ottor Wǽfre, ${ }^{14}$ then Eriol and later changed to Ælfwine ('Elf-friend'), the first man who accidentally finds his way to the Elven kingdoms in the West, and in a dream-like state learns much of their ancient lore. When he wakes up he returns to England and writes down many of the stories he has heard. His tales became half-forgotten with time and

14 The name Ottor is actually equivalent to Old English Ohthere, a character in Beowulf where he is described as the son of the Swedish King Ongenpeow. In the ninth-century Old English translation of Paulus Orosius' Historiarum Adversum Paganos Libri VII ('Seven Books of History against the Pagans') Ohthere together with Wulfstan are voyagers arriving at King Alfred's court and provides the King with stories and information about the lands and peoples surrounding the North Sea (VanderBilt 1998). Tolkien's name Ottor is neither Old English nor Norse; the latter would have been Ottar; it is rather a 'bridge' between these different traditions, connecting them to his secondary world. explain, according to Tolkien, the inconsistencies and the ruined state of later folklore material. This key figure is only described in his earliest writings; his son Christopher Tolkien removed most of this in The Silmarillion, although a few cases remain (cf. Flieger 2012). The elves in Tolkien's view are far removed from the elves of myth and folklore - almost the opposite $^{15}$ - they are described as a noble and aesthetic race which do not age and are closely connected to nature. Following Tolkien they have become a fundamental element in most fantasy-world fictions (on Old Norse elves, see Gunnell 2007). The same can be said of his orcs: evil beings who serve the Dark Lord, which he invented from the word orc-neas in Beowulf, line 112: eotenas ond ylfe ond orc-nēas ('giants and elves and orc-nēas') (Klaeber's Beowulf 2008: 6). Orcs, or similar beings, are something that can be found in most fantasy worlds. Tolkien of course made use of the whole line and interpreted orcs as twisted elves, beings the evil god Morgoth shaped by torturing and corrupting elves in ancient times. For a contemporary audience the reception of Nordic medieval folklore is, both for those who read the books or watch the movies, largely filtered through the works of Tolkien. Tolkien's love of folklore is feelingly expressed in the LOTR (Chapter 8) by the elven King Celeborn who, when Boromir doubts old wives tales, says: 'But do not despise the lore that has come down from distant years; for oft it may chance that old wives keep in memory word of things that once were needful for the wise to know?

Tolkien's continuing popularity - or for some, unpopularity - across the world, may be thanks to his use of highly traditional mythology and ideology that has been comprehensible to millions of readers, and following Peter Jackson's film adaptions, ${ }^{16}$

15 He did maintain a close association between elves and bows, not in the sense that they are beings who have the capacity to inflict diseases with their bows, but as great archers with keen sight. Tolkien's elves remain invisible for most but can be seen by some, which is also close to the elves of folklore, except that Tolkien's elves camouflage themselves to hide from humans. The elves of folklore are often described as small, while Tolkien's elves are closer to human stature, or slightly taller (more like mythological elves in the Old Norse tradition).

16 The LOTR film trilogy: The Fellowship of the Ring (2001), The Two Towers (2002), The Return of the King (2003). The Hobbit film trilogy: An Unexpected Journey (2012), Desolation of Smaug (2013), There and Back Again (scheduled 2014). 
millions of viewers. It is in his highly convincing and extremely well-crafted secondary world that people find encouragement and an escape from a mundane world. ${ }^{17}$ Middle-earth is an imagined world; a fantasy world wrought from traditional narratives and recast in a new mould. It is believable fantasy, and is by no means limited to the English people. Tolkien managed to transform and incorporate old folklore material into his narratives of Middle-earth, and made it accessible to a wide, transnational audience; the idea of elves, dwarfs, wizards, dragons, shapeshifters, talking trees and great heroes still lingers in contemporary culture. Various notions in relation to supernatural beings, and the dynamic traditions formed around them are still relevant today for people of all age categories and social backgrounds, and even though few believe in their existence, they are a part of our culture and recognisable by most. Few would spit out their drinks and scream in terror on seeing a dragon in a movie, or fail to comprehend or accept a fantasy world. Tolkien's works might originally been dedicated to England, but it sparks the imagination of people worldwide and crosses borders, connecting with local bodies of culture, folklore and views of nature and the fantastic. Tolkien's Middle-earth is not static, nor is it a fixed place; it changes on the basis of the personal experience, dreams, hopes and understandings of the different persons reading the books, and is in this regard not only English, but rather cross-cultural. ${ }^{18}$

17 For some it has even been integrated into their religious beliefs, this is especially true of some Wiccagroups. To my awareness this topic have as yet not received much academic interest, but should be fruitful and interesting, not least due to Tolkien's romantic view of nature which harmonises well with ideologies among many Wiccans. Cf. Altensen 2012.

18 A friend of mine is Arabic and lives in a Muslim country in Northern Africa. We have discussed Tolkien on several occasions and found that we were drawn to different descriptions in the books and that we have sometimes interpreted them in different ways based on our background. For example, she compares the elves with beings from legends she heard as a child and has not thought about the myths and legends from Northern Europe as I have.
Tommy Kuusela is a $\mathrm{PhD}$-student in the history of religions at Stockholm University. He's working on a dissertation on giants and giantesses in Old Norse mythology and has published articles on different topics, such as the werewolf in the Old Norse tradition, dogs in Old Norse society and Tolkien. His research interests are Old Norse religion, mythologies, Tolkien, folklore studies and animals from a historical perspective. Email: tommy.kuusela(at)rel.su.se

\section{Bibliography}

Aðalheiður Guðmundsdóttir 2012. 'The origin and development of the Fornaldarsögur as illustrated by Völsunga Saga' in The Legendary Sagas: Origins and Development, ed. Annette Lassen, Agneta Ney and Ármann Jakobsson (Reykjavík, University of Iceland Press), pp. 59-81

Altensen, Markus Altena 2012. 'The spiritual milieu based on J.R.R. Tolkien's literary mythology' in the Handbook of Hyper-real Religions, ed. Adam Possamai, Brill Handbooks on Contemporary Religion, 5 (Leiden and Boston, Brill), pp. 185-204

Anderson, Benedict 2006. Imagined Communities: Reflections on the Origin and Spread of Nationalism, rev. edn (London, Verso)

Andersson, Douglas A. 2002. The Annotated Hobbit (Boston and New York, Houghton Mifflin)

Andersson, Theodore M. 1980. The Legend of Brynhild, Islandica, 43 (Ithaca and London, Cornell University Press)

Atherton, Mark 2012. There and Back Again: J.R.R. Tolkien and the Origins of the Hobbit (London and New York, I.B. Tauris)

Battles, Paul 2005. 'Dwarfs in Germanic literature: Deutsche Mythologie or Grimm's myths?' in The Shadow-Walkers: Jacob Grimm's Mythology, ed. Tom Shippey, Arizona Center for Medieval and Renaissance Studies, 291 (Tempe, AZ, Brepols), pp. 29-82

Bringéus, Nils-Arvid 1966. Gunnar Olof Hyltén-Cavallius. En studie kring Wärend och wirdarne, Nordiska museets handlingar, 63 (Stockholm, Nordiska Museet)

Burns, Marjorie 2005. Perilous Realms: Celtic and Norse in Tolkien's Middle-earth (University of Toronto Press)

Chance, Jane 2004. 'A mythology for England?' in Tolkien and the Invention of Myth: A Reader, by Jane Chance (Lexington, The University of Kentucky Press), pp. $1-16$ 
Dronke, Ursula 1997. Poetic Edda, vol. 2, Mythological Poems (Oxford, Clarendon Press)

Edda. Die Lieder des Codex Regius, ed. Gustav Neckel, based on Hans Kuhn, 3 rd rev. edn (Heidelberg, Carl Winter Universitätsverlag, 1962)

Eriksson, Karin 2013. 'Några reflektioner kring frågan om George Stephens som samlare och upptecknare' in Mellan nation och tradition. Idéströmningar i $1800-$ talets insamlingar av folklore, ed. Ulf Palmenfelt, Acta Academiae Regiae Gustavi Adolphi, 124 (Uppsala, Gustav Adolf Akademien), pp. 51-62

Fimi, Dimitra 2006. "Mad" elves and "elusive beauty": some strands of Tolkien's mythology', Folklore 117, pp $155-70$

Flieger, Verlyn 2012 (2000). 'The footsteps of Ælfwine' in Green Suns and Faërie: Essays on J.R.R. Tolkien by Verlyn Flieger (The Kent State University Press), pp. 74-88

Garth, John 2003. Tolkien and the Great War: The Threshold of Middle-Earth (Boston, Houghton Mifflin)

Glosecki, Stephen O. 1989. Shamanism and Old English Poetry, Albert Bates Lord Studies in Oral Tradition, 2 (New York and London, Garland)

Gunnell, Terry 2007. 'How elvish were the Álfar?' in Constructing Nations, Reconstructing Myth: Essays in Honour of T. A. Shippey, ed. Andrew Wawn, Making the Middle Ages, 9 (Turnhout, Brepols), pp. 111-30

Honko, Lauri. 1998. 'Introduction: oral and semiliterary epics' in The Epic: Oral and Written, ed. L. Honko, J. Handoo and J. M. Foley (Mysore, Central Institute of Indian Languages)

-2000. 'Text as process and practice: the textualization of oral epics' in Textualization of Oral Epics, ed. Lauri Honko (Berlin and New York, Mouton de Gruyter), pp. 3-54.

-2013. 'The folklore process' in Theoretical Milestones: Selected Writings of Lauri Honko, ed. Pekka Hakamies and Anneli Honko, FF Communications, 304 (Helsinki, Academia Scientiarum Fennica), pp. 29-54

Klaeber's Beowulf, ed. R. D. Fulk, Robert E. Bjork and John D. Niles, 4th edn (University of Toronto Press, 2008 (1950))

Kumar, Krishan 2003. The Making of English National Identity (Cambridge University Press)

Kuusela, Tommy 2012. 'Varulven i fornnordisk tradition' in Varulven i svensk folktradition by Ella Odstedt, ed. Per Faxneld and Per Norström (Malört förlag), pp. 320-52

-2013. 'Bakgrund till J.R.R. Tolkiens världar. Kalevala och andra källor', Chaos 59, pp. 97-123

Kvideland, Reimund, and Henning K. Sehmsdorf 1989. 'Nordic folklore studies today' in Nordic Folklore: Recent Studies, ed. R. Kvideland and H. K. Sehmsdorf (Bloomington, Indiana University Press), pp. 3-11

Lindow, John 2005 (1986). 'Mythology and mythography' in Old Norse-Icelandic Literature: A Critical Guide, ed. Carol Clover and John Lindow, Medieval Academy Reprints for Teaching, 42 (University of Toronto Press), pp. 21-67
Panzer, Friedrich 1910. Studien zur germanischen Sagengeschichte, vol. 1, Beowulf (München)

Petty, Anne C. 2004. 'Identifying England's Lönnrot', Tolkien Studies 1, pp. 69-84

Roper, Jonathan 2012. 'England: the land without folklore?' in Folklore and Nationalism in Europe during the Long Nineteenth Century, ed. Timothy Baycroft and David Hopkin, National Cultivation of Culture, 4 (Leiden and Boston, Brill), pp. 227-53

The Saga of King Hrolf Kraki, trans. Jesse L. Byock (London, Penguin Books, 1998)

Salus, Peter H., and Paul Beekman Taylor 1969. 'Eikinskjaldi, Fjalarr, and Eggpér: notes on dwarves and giants in the Völuspá, Neophilologus 53(1), pp. 76-81

Sammons Martha C. 2010. War of the Fantasy Worlds: C.S. Lewis and J.R.R. Tolkien on Art and Imagination (Oxford, Praeger)

Shippey, Tom 2001 (2000). J. R. R. Tolkien: Author of the Century (London, Harper Collins)

-2005. 'Alias oves habeo: the elves as a category problem' in The Shadow-Walkers: Jacob Grimm's Mythology, ed. Tom Shippey, Arizona Center for Medieval and Renaissance Studies, 291 (Tempe, AZ, Brepols), pp. 157-87

-2007 (2000). 'Grimm, Grundtvig, Tolkien: nationalism and the invention of mythologies' in Roots and Branches: Selected Papers on Tolkien by Tom Shippey, ed. Thomas Honegger, Cormarë Series 11 (Jena, Walking Tree Publishers), pp. 79-96

Simek, Rudolf 2005. Mittelerde. Tolkien und die germanischen Mythologie (München, Beck)

Snorri Sturluson 1916. Prose Edda, trans. Arthur Gilchrist Brodeur, Scandinavian Classics, 5 (New York, The American-Scandinavian Foundation)

Stenström, Anders 1995. 'A mythology? For England?' in Proceedings of the J.R.R. Tolkien Centenary Conference, Keble College, Oxford 1992, ed. Patricia Reynolds and Milton Keynes (Altadena, Mythopoeic Press), pp. 310-14

Tolkien, J. R. R. 2000 (1981). The Letters of J.R.R. Tolkien, ed. Humphrey Carpenter, exp. edn (New York, Houghton Mifflin)

-2002. Beowulf and the Critics, ed. Michael Drout, Arizona Center for Medieval and Renaissance Studies, 248 (Tempe, AZ, Arizona Center for Medieval and Renaissance Studies)

-2008. Tolkien on Fairy-stories, ed. Verlyn Flieger and Douglas A. Andersson, exp. edn, with commentary and notes (London, Harper Collins)

VanderBilt, Deborah 1998. 'Translation and orality in the Old English Orosius', Oral Tradition 13(2), pp. 377-97 